\title{
Effect of Sugarcane Bagasse Fibre on the Behavior of Geopolymer Concrete under Sulphate Attack
}

\author{
T. Srinivas ${ }^{1}$, Thandra Arun $^{2}$, N.V.Ramana $\mathrm{Rao}^{3}$ \\ ${ }^{1}$ Professor, GRIET, Hyderabad, India. \\ ${ }^{2}$ P.G.Student, GRIET, Hyderabad, India. \\ ${ }^{3}$ Professor, JNTUH, Hyderabad, India.
}

\begin{abstract}
The use of various fibres such as steel, glass, sugarcane bagasse, and others has a considerable impact on the fresh and hardened properties of concrete. Sugarcane bagasse fibre is a byproduct from the sugarcane industry that can be reused as a concrete fibre. This paper objective is to work on the behaviour of sugarcane bagasse fibre on low calcium fly ash and slag based geopolymer concrete of G40 which is equivalent to M40 grade, when it is exposed to 5\% sulphate attack with the help of experiments. The specimens were casted, GPC and GPCF Cured in an oven at $60^{\circ} \mathrm{C}$ for 24 hours, then let to cure in the atmosphere until the test is complete. After 28 days, the specimens were immersed in sulphates such as $\mathrm{Na} 2 \mathrm{SO} 4$ and $\mathrm{MgSO} 4$ for 15, 45, and 75 days, and then tested according to codal standards on 15,45 , and 75 days. The comparisons were made in a controlled concrete environment (CC), controlled concrete with sugarcane bagasse fibre (CCF), geopolymer concrete (GPC) and geopolymer concrete with sugarcane bagasse fibre (GPCF). From the results it is observed that CCF and GPCF showed more resistant than CC and GPC when it is subjected to sulphate attack.
\end{abstract}

\section{Introduction}

Construction field is the fastest growing field in worldwide. Cement is the main constituent in the controlled concrete and behaves as a binder material. For production of OPC requires large amount of raw materials. During the production of OPC it emits large amounts of carbon dioxide into the atmosphere. For manufacturing of 1 ton of cement about 1.5 tonnes of raw materials are used. Each tonne of cement produced releases about one tonne of $\mathrm{CO} 2$. It is the most important issue from a long-term perspective. OPC also emits heat during hydration process. In this case geopolymer concrete is the best alternative. Geopolymer concrete is made by reacting aluminate and silicate-bearing materials with a caustic activator. Iron and metal production produces byproducts such as flyash or slag used in concrete helps to lead a cleaner environment. By use of these byproducts produced from various industries results in environmental and economic benefit. Geopolymer concrete does not produce heat during polymerisation. By use of geopolymer concrete we can reduce the usage of ordinary Portland cement hence the production of cement decreases and also green house gases releasing into the atmosphere decreases. Utilization of various fibres like steel, glass, sugarcane bagasse etc, significantly influences fresh and hardened properties of concrete. Sugarcane bagasse fibre is a by-product from sugar industries and can be used as a fibre in concrete.

\section{Materials}

\subsection{Ordinary Portland Cement}

Ordinary Portland cement with a grade of 53 was implemented in this research. A range of tests were performed on physical properties. The specific gravity of cement is measured to be 3.16 . 


\subsection{Fine Aggregate (FA)}

Local sources are used to obtain the fine aggregate. It is free of contaminants such as silt, clay, and organic materials. Physical properties of fine aggregate such as fineness modulus, gradation, bulk density, and specific gravity were tested in line with IS:2836. Zone-II of IS: 383-1970 has been confirmed in the sand. Fine aggregate has a specific gravity of 2.64 .

\subsection{Coarse Aggregate}

In this experiment, coarse aggregate particles with a diameter of $20 \mathrm{~mm}$ were utilised. The parameters of coarse aggregate are determined using the IS:23861963 standard. It is found that coarse aggregate has a specific gravity of 2.60 .

\subsection{Fly Ash}

In this experiment low calcium class $\mathrm{F}$ flyash is used.

\subsection{GGBS (ground granulated blast furnace slag):}

It's a byproduct from the steel industry. GGBS is a molten mixture of calcium silicates and other bases generated simultaneously with $\mathrm{Fe}$ in a blast furnace.

\subsection{Water:}

According to IS 456:2000, water should be free of pollutants and other compounds, and oils should be used for concrete mixing.

\subsection{Sodium hydroxide:}

It's most widely utilized as a geopolymerization activator, which is one of the main ingredients in geopolymer concrete. White solids are the physical appearance of sodium hydroxide pellets.

Table 1. Physical properties of $\mathrm{NaOH}$

\begin{tabular}{|l|l|}
\hline Molar mass & $40 \mathrm{gm} / \mathrm{mol}$ \\
\hline Appearance & White solid \\
\hline Density & $2.1 \mathrm{gr} / \mathrm{cc}$ \\
\hline Melting point & $318^{0} \mathrm{c}$ \\
\hline Boiling point & $1390^{\circ} \mathrm{cc}$ \\
\hline $\begin{array}{l}\text { Amount of heat liberated when } \\
\text { dissolved in water }\end{array}$ & $266 \mathrm{cal} / \mathrm{gr}$ \\
\hline
\end{tabular}

\subsection{Sodium silicate solution:}

Sodium silicate solution is an alkaline liquid that plays an important function as an activator in the geopolymerisation process. Porosity is also reduced. If there is more calcium hydroxide in concrete, it bonds to the surface, enhancing durability and water resistance.

Table 2. Properties of $\mathrm{Na} 2 \mathrm{Sio} 3$ solution

\begin{tabular}{|l|l|}
\hline Specific gravity & 1.57 \\
\hline Molar mass & $123.06 \mathrm{gm} / \mathrm{mol}$ \\
\hline $\mathrm{Na} 2 \mathrm{O}$ (by mass) & $15.35 \%$ \\
\hline $\mathrm{SiO} 2$ (by mass) & $30.00 \%$ \\
\hline Water (by mass) & $56.00 \%$ \\
\hline Weight ratio (SiO2 to $\mathrm{Na} 2 \mathrm{O})$ & 2.09 \\
\hline Molarity ratio & 0.98 \\
\hline
\end{tabular}

\subsection{Constituents of geopolymer}

\subsubsection{Source materials}

Material containing primarily silicon and aluminium in amorphous form is a viable source for geopolymer production. In the past, several minerals and industrial byproducts were studied.

\subsubsection{Alkaline activators}

A mixture of sodium slilicate and sodium hydroxide is the most frequent alkaline activator used in geopolymerisation.

\subsubsection{Super plasticizer}

Super plasticizer (sulphonated naphthalene formaldehyde) is used as admixture which reduces water content and increases the workability of concrete. It is added in $2 \%$ to the binder.

\subsection{Sugarcane bagasse fibre}

Sugarcane bagasse is a byproduct from sugarcane industry. After sugarcane stalks are crushed to obtain juice, it leaves a dry pulpy fibrous residue. Fiber has a 66.7 aspect ratio.

\section{Experimental investigation}

\subsection{General}

The behaviour of sugarcane bagasse fibre on low calcium flyash and slag based geopolymer concrete exposed to $5 \%$ sulphate solutions for up to 2.5 months of $\mathrm{CC}, \mathrm{CCF}$, and GPCF correspondingly is presented in this work. Alkaline solution is made up of sodium hydroxide and sodium silicate. The compressive strength is highest when the ratio of $\mathrm{Na} 2 \mathrm{SiO} 3$ to $\mathrm{NaOH}$ is 2.5 , and when the ratio of 
$\mathrm{SiO} 2$ to $\mathrm{Na} 2 \mathrm{O}$ is 2. After a one-day rest period, $100 \mathrm{mmX} 100 \mathrm{mmX} 100 \mathrm{~mm}$ cubes of sugarcane bagasse fibre reinforced geopolymer concrete were cast. The specimens were oven cured for 24 hours at 60 degrees Celsius and then ambient cured for the rest of the time. For controlled concrete, a traditional approach of casting the same size cubes and keeping them under water for curing was used. After 28 days, the specimens were immersed in sulphates such as $\mathrm{MgSO} 4$ and $\mathrm{Na} 2 \mathrm{SO} 4$ for 15,45 , and 75 days, and then the sulphate attack resistance of CC, $\mathrm{CCF}$, GPC, and sugarcane bagasse fibre reinforced geopolymer concretes exposed to a $5 \%$ concentration of $\mathrm{Na} 2 \mathrm{SO} 4$ and $\mathrm{MgSO} 4$ sulphates was measured in terms of weight loss and compressive strength. The Acid Attack Factors (AAFs) and Acid Durability Factors (ADFs) of controlled and sugarcane bagasse fibre reinforced geopolymer concrete exposed to $5 \%$ concentrations of various sulphates are also investigated to determine their resistance to sulphate attack, and the results are compared.

\subsection{Mixing and Casting of Geopolymer Concrete}

The traditional concrete processes can be used to make geopolymer concrete. In laboratory flyash, GGBS, sugarcane bagasse fibre and aggregates were mixed for 3minutes when in dry condition. Superplasticizer is mixed with alkaline liquid and extra water if any.

The liquid component was mixed in with the dry ingredients, and the mixing took around four minutes. The new concrete was cast and compacted using the same processes as Portland cement concrete. Conventional slump test is done for evaluating the workability of fresh concrete.

\section{Test Results}

\subsection{Loss of weight and compressive strength}

When exposed to a $5 \%$ concentration of $\mathrm{MgSO} 4$ and $\mathrm{Na} 2 \mathrm{SO} 4$ solutions, the weight and compressive strength of $\mathrm{CC}, \mathrm{CCF}, \mathrm{GPC}$, and sugarcane bagasse fibre reinforced geopolymer concrete is lost in percentage.

\subsection{Acid Durability Factors (ADFs) and Acid Attack Factors (AAFs)}

\subsubsection{Acid Durability Factors (ADFs)}

The Acid durability factors can be calculated as follows

Acid Durability Factors $=\mathrm{Sr}(\mathrm{N} / \mathrm{M})$

Where
$\mathrm{Sr}=$ relative strength over a duration of $\mathrm{N}$ days ( percent )

$M=$ Number of days till the exposure is to be ended. $\mathrm{N}$ is the number of days that the durability factor is required.

The Acid Attack test was stopped after 60 days. So $\mathrm{M}$ is equal to 60 .

\subsubsection{Acid Attack Factors (AAFs)}

For each of two cubes, the surface degradation of each corner of the affected face and the opposite face is measured in millimetres, and the acid attack factors per face are determined as follows:

Acid Attack Factors (AAFs) and Acid Durability Factors (ADFs) of $\mathrm{CC}, \mathrm{CCF}, \mathrm{GPC}$, and sugarcane bagasse fibre reinforced geopolymer concrete specimens exposed to $5 \% \mathrm{MgSO} 4$ and $\mathrm{Na} 2 \mathrm{SO} 4$ solutions are shown in the figures.

Table 3. The \%loss of compressive strength when immersed in 5\% MgSO4 solution.

\begin{tabular}{|c|c|c|c|c|}
\hline & \multicolumn{2}{|c|}{$\begin{array}{c}\text { Strength } \\
\text { before } \\
\text { immersion }\end{array}$} & \multicolumn{3}{|c|}{ strength after immersion } \\
\hline & & $\mathbf{1 5}$ & $\mathbf{4 5}$ & $\mathbf{7 5}$ \\
\hline CC & 49.2 & 46.45 & 45.38 & 44.28 \\
\hline $\begin{array}{c}\text { \% of strength } \\
\text { loss }\end{array}$ & & 5.58 & 7.76 & 9.98 \\
\hline CCF & 55.30 & 52.78 & 51.63 & 50.57 \\
\hline $\begin{array}{c}\text { \% of strength } \\
\text { loss }\end{array}$ & & 5.03 & 6.96 & 8.76 \\
\hline GPC & 50.5 & 48.70 & 47.58 & 46.88 \\
\hline $\begin{array}{c}\% \text { of strength } \\
\text { loss }\end{array}$ & & 3.56 & 5.78 & 7.16 \\
\hline GPCF & 56.80 & 55.23 & 54.00 & 53.28 \\
\hline $\begin{array}{c}\% \text { of strength } \\
\text { loss }\end{array}$ & & 3.24 & 5.24 & 6.41 \\
\hline
\end{tabular}

Table 4. The \%loss of compressive strength when immersed in 5\% Na2SO4 solution.

\begin{tabular}{|l|r|r|r|r|}
\hline & \multicolumn{2}{|l|}{$\begin{array}{l}\text { Strength } \\
\text { before } \\
\text { immersion }\end{array}$} & \multicolumn{3}{|c|}{ strength after immersion } \\
\hline & & $\mathbf{1 5}$ & $\mathbf{4 5}$ & $\mathbf{7 5}$ \\
\hline CC & 49.2 & 46.9 & 45.76 & 44.34 \\
\hline $\begin{array}{l}\text { \% strength } \\
\text { loss }\end{array}$ & & 4.67 & 6.99 & 9.86 \\
\hline CCF & 55.30 & 52.83 & 51.77 & 50.43 \\
\hline $\begin{array}{l}\% \text { strength } \\
\text { loss }\end{array}$ & & 4.45 & 6.37 & 8.80 \\
\hline GPC & 50.5 & 48.84 & 47.54 & 47.09 \\
\hline $\begin{array}{l}\text { \% strength } \\
\text { loss }\end{array}$ & & 3.29 & 5.86 & 6.75 \\
\hline GPCF & 56.80 & 55.59 & 53.73 & 53.31 \\
\hline $\begin{array}{l}\% \text { strength } \\
\text { loss }\end{array}$ & & 2.12 & 5.40 & 6.13 \\
\hline
\end{tabular}




\begin{tabular}{|c|c|c|c|c|}
\hline & $\begin{array}{c}\text { Weights } \\
\text { before } \\
\text { immersio } \\
\text { n }\end{array}$ & \multicolumn{3}{|c|}{ Weights after immersion } \\
\hline & & $\mathbf{1 5}$ & $\mathbf{4 5}$ & $\mathbf{7 5}$ \\
\hline CC & 2.49 & 2.50 & 2.50 & 2.51 \\
\hline $\begin{array}{c}\text { \% weight } \\
\text { loss }\end{array}$ & & -0.41 & -0.41 & -0.42 \\
\hline CCF & 2.44 & 2.44 & 2.44 & 2.45 \\
\hline $\begin{array}{c}\text { \% weight } \\
\text { loss }\end{array}$ & & -0.4 & -0.4 & -0.41 \\
\hline GPC & 2.29 & 2.30 & 2.31 & 2.32 \\
\hline $\begin{array}{c}\% \text { weight } \\
\text { loss }\end{array}$ & & -0.44 & -0.89 & -0.9 \\
\hline GPCF & 2.34 & 2.34 & 2.35 & 2.36 \\
\hline $\begin{array}{c}\text { \% weight } \\
\text { loss }\end{array}$ & & -0.26 & -0.82 & -0.84 \\
\hline
\end{tabular}

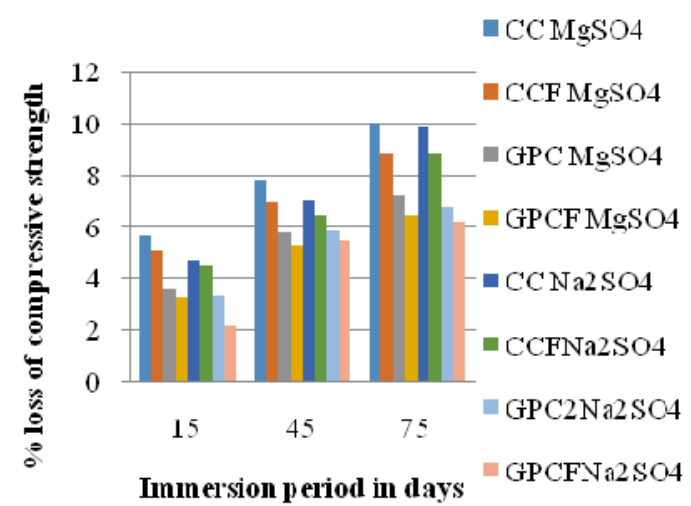

Fig.1. Percentage loss of compressive when immersed in $\mathrm{MgSO} 4$ and $\mathrm{Na} 2 \mathrm{SO} 4$ solutions

Table 5. \% loss of weight when immersed in $\mathrm{MgSO} 4$ solution

\begin{tabular}{|c|c|c|c|c|}
\hline & $\begin{array}{c}\text { Weights } \\
\text { before } \\
\text { immersion }\end{array}$ & \multicolumn{3}{|c|}{ Weights after immersion } \\
\hline & & $\mathbf{1 5}$ & $\mathbf{4 5}$ & $\mathbf{7 5}$ \\
\hline CC & 2.46 & 2.47 & 2.48 & 2.48 \\
\hline $\begin{array}{c}\% \text { of } \\
\text { weight } \\
\text { loss }\end{array}$ & & & & \\
\hline CCF & 2.32 & 2.33 & 2.34 & 2.34 \\
\hline $\begin{array}{c}\text { \% of } \\
\text { weight } \\
\text { loss }\end{array}$ & & & & \\
\hline GPC & 2.27 & 2.27 & 2.28 & 2.28 \\
\hline $\begin{array}{c}\% \text { of } \\
\text { weight } \\
\text { loss }\end{array}$ & & & & \\
\hline GPCF & 2.38 & 2.38 & 2.39 & 2.39 \\
\hline $\begin{array}{c}\% \text { of } \\
\text { weight } \\
\text { loss }\end{array}$ & & & & \\
\hline
\end{tabular}

Table 6. \% loss of weight when immersed in Na2SO4 solution

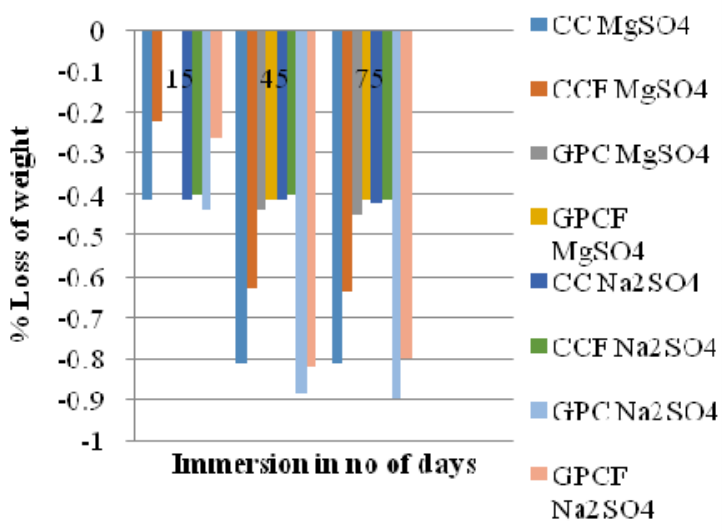

Fig .2. Percentage loss of weight when immersed in $\mathrm{MgSO} 4$ and $\mathrm{Na} 2 \mathrm{SO} 4$ solutions

Table 7. Acid durability factors when immersed in $\mathrm{MgSO} 4$ solution

\begin{tabular}{|c|c|c|c|}
\hline & \multicolumn{3}{|c|}{ MgSO4 } \\
\hline & \multicolumn{3}{|c|}{ Acid durability factors } \\
\hline & $\mathbf{1 5}$ & $\mathbf{4 5}$ & $\mathbf{7 5}$ \\
\hline CC & 18.89 & 55.34 & 90.02 \\
\hline CCF & 19.08 & 56.01 & 91.44 \\
\hline GPC & 19.28 & 56.53 & 92.83 \\
\hline GPCF & 19.44 & 57.04 & 93.80 \\
\hline
\end{tabular}

Table 8. Acid attack factors when immersed in $\mathrm{MgSO} 4$ solution

\begin{tabular}{|c|c|c|c|}
\hline & \multicolumn{3}{|c|}{ Acid attack factors } \\
\hline & \multicolumn{3}{|c|}{ MgSO4 } \\
\hline & $\mathbf{1 5}$ & $\mathbf{4 5}$ & $\mathbf{7 5}$ \\
\hline CC & 0.135 & 0.459 & 0.685 \\
\hline CCF & 0.067 & 0.292 & 0.343 \\
\hline GPC & 0.015 & 0.125 & 0.220 \\
\hline GPCF & 0.011 & 0.015 & 0.018 \\
\hline
\end{tabular}

Table 9. Acid durability factors when immersed in $\mathrm{NaSO} 4$ solution

\begin{tabular}{|c|c|c|c|}
\hline & \multicolumn{3}{|c|}{ Acid durability factor } \\
\hline & \multicolumn{3}{|c|}{ Na2SO4 } \\
\hline & $\mathbf{1 5}$ & $\mathbf{4 5}$ & $\mathbf{7 5}$ \\
\hline CC & 19.06 & 55.80 & 90.12 \\
\hline CCF & 19.11 & 56.16 & 91.19 \\
\hline GPC & 19.34 & 56.48 & 93.24 \\
\hline GPCF & 19.57 & 56.75 & 93.85 \\
\hline
\end{tabular}


Table 10. Acid Attack factors when immersed in $\mathrm{NaSO} 4$ solution

\begin{tabular}{|c|c|c|c|}
\hline & \multicolumn{3}{|c|}{ Acid attack factor } \\
\hline & \multicolumn{3}{|c|}{ Na2SO4 } \\
\hline & 15 & 45 & 75 \\
\hline CC & 0.135 & 0.439 & 0.675 \\
\hline CCF & 0.068 & 0.274 & 0.440 \\
\hline GPC & 0.015 & 0.110 & 0.205 \\
\hline GPCF & 0.012 & 0.017 & 0.0201 \\
\hline
\end{tabular}

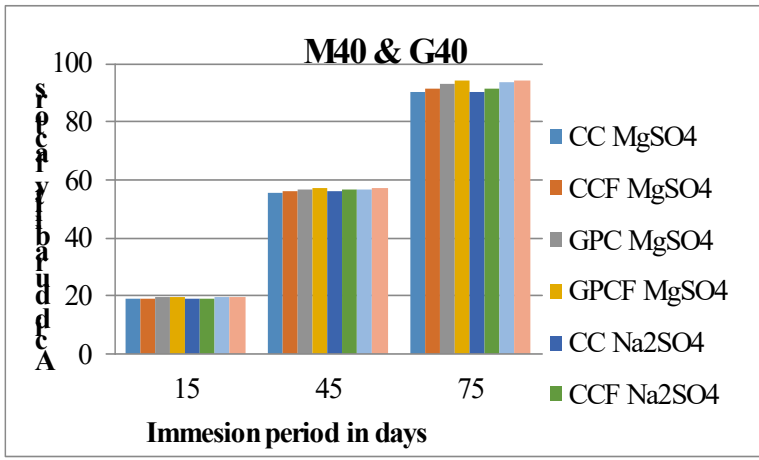

Fig.3. Acid durability factors when immersed in $\mathrm{MgSO} 4$ and $\mathrm{Na} 2 \mathrm{SO} 4$ solutions

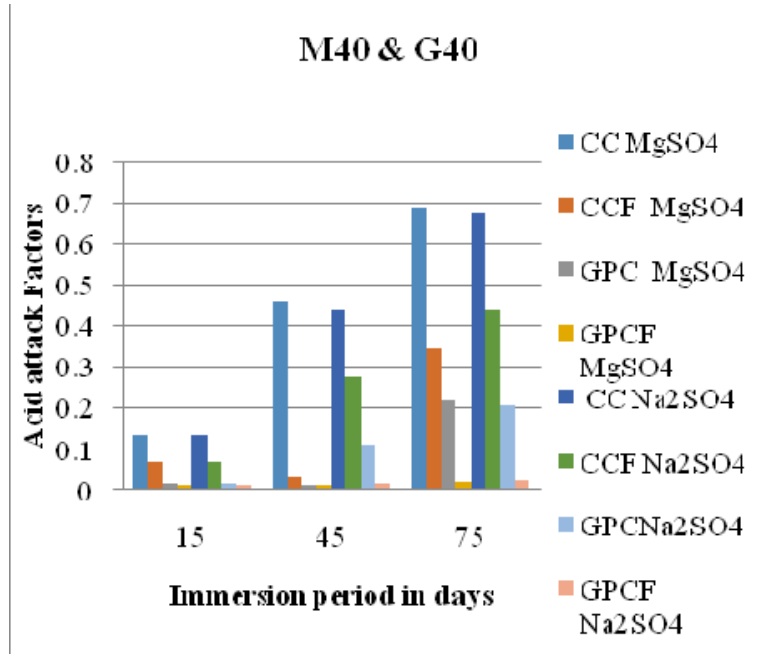

Fig.4. Acid Attack factors when immersed in $\mathrm{MgSO} 4$ and $\mathrm{Na} 2 \mathrm{SO} 4$ solutions

\section{Conclusions}

From the experimental investigations, following specific conclusions have been drawn:
1. The percentage of loss of compressive strength and weights are increased when specimens are exposed to magnesium and sodium sulphates. Loss of compressive strength and weights are increased as the immersion period increases for $\mathrm{CC}, \mathrm{CCF}$, GPC and GPCF.

2. The loss of compressive strength of CCF and GPCF decreased by $10.75 \%$ and $9.18 \%$ respectively when it is compared with $\mathrm{CC}$ and GPC under sodium sulphate attack for a period 75 days.

3. The loss of compressive strength of CCF and GPCF decreased by $12.22 \%$ and $10.48 \%$ respectively when it is compared with CC and GPC under magnisum sulphate attack for a period 75 days

4. Due to its alkalinity of concrete mass and high impermeability, sugarcane bagasse fibre geopolymer concrete is more durable in terms of 'Acid Durability Factors' and less attacked in terms of 'Acid Attack Factors' than $\mathrm{CC}, \mathrm{CCF}$, and $\mathrm{GPC}$ at all ages and can perform better in severe aggressive environments.

5. Since the weight and strength loss are more, it may be deduced that magnesium sulphate is more harsh than sodium environment. White deposits were seen on the specimens' surfaces, which gradually transform from soft and flaky shape to hard and round shape when exposed to magnesium sulphate compared to sodium sulphate solution.

\section{References}

1. Arslan Akbar, Furqan Farooq, Muhammad Shafique, Fahid Aslam, Rayed Alyousef, Hisham AbdulJabbar, Jou. of Bui. Engg, 33, 101492 (2021)

2. Shubha Vinaya A.S, Sachitha H.D ,Ravindra M.L,Darshan P,Lakshmi P.S. Int. Jour. of Engineering Research in Mech and Civ Engineering, 05, 8 (2020)

3. Henry A Colorado, John F Zapata, J. Mater. Environ. Sci, 10, 1162-1171 (2019)

4. R.Y. Nkwaju, J.N.Y. Djobo, J.N.F. Nouping ,P.W.M. Huisken, J.G.N. Deutou, L. Courard. Applied Clay Science, 183, 105-333 (2019).

5. Víctor Alberto Franco-Lujan, Marco Antonio Maldonado-Garcia, Jose Manuel MendozaRangel, Pedro Montes-Garcia, Const. and Buil. Materials, 198, 608-618 (2019)

6. Dr.T Srinivas ,Dr. N V Ramana Rao, Int. Jour. of Civil Engineering and Tech. 10, 02, (2019). 
7. T. Srinivas, R. N. Koushik, Int. Jour. of Innovative Tech. and Exploring Engineering, 8 ,12 (2019)

8. J.C. Arenas-Piedrahita, P. Montes-García, J.M. Mendoza-Rangel, H.Z. López Calvo, P.L. Valdez-Tamez, J. Martínez-Reyes. Const. and Bui. Materials, 105, 69-81 (2016)

9. T.Srinivas and M. Abinay Raj, Int. J. of Eng.and Adv. Tech. (IJEAT), ISSN: 2249 8958, Volume-8 Issue-6 (2019)

10. Srinivas Rao J, S K Tummala, Kuthuri N R, Indonesia Journal of Electrical Engg. \& Computer Science, 21 (723), 2020

11. T.srinivas and P. Manoj Anand, Int. J. of Innov. Tech. and Explor. Eng.g (IJITEE), ISSN: 2278-3075, Volume-8 Issue-12 (2019)

12. T.Srinivas and G. Sukesh Reddy, Int. J. of Eng.and Adv. Tech. (IJEAT), ISSN: 2249 8958, Volume-9 Issue-1 (2019)

13. A.U. Haq, A. K. Kavit, T. Rao, T. Buddi, D. Baloji, K. Satyanarayana, S. K. Singh, Materials Today: $\quad$ Proceedings, 18 , 4589 (2019)

14. T.Srinivas and R. N. Koushik, Int. J. of Innov. Tech. and Explor. Eng.g (IJITEE), ISSN: 2278-3075, Volume-8 Issue-12 (2019), PP $112-117$

15. B. J. Varghese and P. B. Bobba, " 2016 IEEE 1st International Conference on Power Electronics, Intelligent Control and Energy Systems (ICPEICES), 2016, pp. 1-5

16. K. Sai Gopi, Dr. T. Srinivas and S. P. Raju V, E3S Web of Conferences ICMED 184, 01084GRIET, 28-29 February, https://doi.org/10.1051/e3sconf/202018401108 4(2020)

17. Jagannadha Kumar, M.V., Jagannadha Rao, K., Dean Kumar, B., Srinivasa Reddy, V., Int. J. of Civil Eng. and Tech., 9(7), pp. 1133-1141 (2018)

18. Ganta, J.K., Seshagiri Rao, M.V., Mousavi, S.S., Srinivasa Reddy, V., Bhojaraju, C., Structures 28, pp. 956-972 (2020)

19. Naidu, K.S.S.T., Rao, M.V.S., Reddy, V.S., Int. J. of Innov. Tech. and Explor. Eng.g (IJITEE), 8(9 Special Issue 2), pp. 641-642 (2019)

20. Chandana Priya, C., Seshagiri Rao, M.V., Srinivasa Reddy, V., Int. J. of Civil Eng. and Tech., 9(11), pp. 2218-2225 (2018)

21. Satya Sai Trimurty Naidu, K., Seshagiri Rao, M.V., Srinivasa Reddy, V., Int. J. of Civil Eng. and Tech., 9(11), pp. 2383-2393 (2018)

22. Supriya, Y., Srinivasa Reddy, V., Seshagiri Rao, M.V., Shrihari, S., Int. J. of Rec. Tech. and Engi., 8(3), pp. 5381-5385 (2019)

23. Kotkunde, N., Krishna, G., Shenoy, S.K., Gupta, A.K., Singh, S.K. International Journal of Material Forming, 10 (2), pp. 255-266 (2017)

24. Govardhan, D., Kumar, A.C.S., Murti, K.G.K., Madhusudhan Reddy, G. Materials and
Design, 36, pp. 206-214. (2012)

25. Kumar, P., Singhal, A., Mehta, S., Mittal, A. Journal of Real-Time Image Processing, 11 (1), pp. 93-109. (2016)

26. Raghunadha Reddy, T., Vishnu Vardhan, B., Vijayapal Reddy, P. International Journal of Applied Engineering Research, 11 (5), pp. 3092-3102 (2016)

27. M. Vaishnavi and P. B. Bobba, 2019 IEEE 5th International Conference for Convergence in Technology (I2CT), 2019, pp. 1-6

28. K. satyanarayana, S. K. Singh, T. Buddi, K. Anil and A. Ul Haq, Advances in Materials and Processing Technologies, 6(2), 365 (2020)

29. Hussaini, S.M., Krishna, G., Gupta, A.K., Singh, S.K. Journal of Manufacturing Processes, 18, pp. 151-158 (2015) 